\title{
PENGARUH MODEL PROBLEM BASED INTRODUCTION (PBI) TERHADAP PRESTASI BELAJAR IPS KOMPETENSI MENGENAL JENIS-JENIS USAHA DAN KEGIATAN EKONOMI DI INDONESIA
}

\author{
Nursyamsiah \\ STIT Sunan Giri Bima \\ Email: nursyamsiah_nato08@yahoo.co.id
}

\begin{abstract}
This study aims to find out student learning outcomes through the application of PBI Model in IPS learning, knowing student activity through the application of Problem Based Introduction Model in IPS learning. This research was conducted in the form of Classroom Action Research. The stages are: Action Planning, Action Implementation, Evaluation / Observation and Reflection. The subjects of this study are students of class $\mathrm{V}$ semester 1 year lesson 2013/2014 as many as 24 people. The research data are: (1). Student learning outcomes are collected through a learning result test. (2). Student activity is collected through observation guidelines. Data were analyzed descriptively qualitative. From result of data analysis found that: (1). Average student learning outcomes 70.77 Classical completeness $83.33 \%$ (2). Student activity in following learning increases at every meeting. Based on the above data, the application of PBI model can be used as one of the strategies in the learning process.
\end{abstract}

Keyword: Influence, Learning Achievement, and Problem Based Introduction Model (PBI) 
Abstrak: Penelitian ini bertujuan yaitu mengetahui hasil belajar siswa melalui penerapan Model PBI dalam pembelajaran IPS, mengetahui aktivitas siswa melalui penerapan Model Problem Based Introduction dalam pembelajaran IPS. Penelitian ini dilakukan dalam bentuk Penelitian Tindakan Kelas (Classroom Action Research). Tahapan-tahapan yang dilaksanakan adalah: Perencanaan Tindakan, Pelaksanaan Tindakan, Evaluasi/Observasi dan Refleksi. Subyek penelitian ini adalah siswa kelas $\mathrm{V}$ semester 1 tahun pelajaran 2013/2014 sebanyak 24 orang. Data penelitian adalah : (1). Hasil belajar siswa dikumpulkan melalui tes hasil belajar. (2). Aktivitas siswa dikumpulkan melalui pedoman observasi. Data dianalisis secara deskriptif kualitatif. Dari hasil analisa data ditemukan bahwa : (1). Rerata hasil belajar siswa 70,77 Ketuntasan klasikal $83.33 \%$ (2). Aktivitas siswa dalam mengikuti pembelajaran meningkat pada setiap pertemuan. Berdasarkan hasil data diatas maka penerapan model PBI dapat digunakan sebagai salah satu strategi dalam proses pembelajaran.

Kata kunci: Pengaruh, Prestasi Belajar, dan Model Problem Based Introduction (PBI)

\section{Pendahuluan}

Pendidikan menduduki peran penting dalam upaya untuk meningkatkan kualitas manusia, baik secara sosial, spiritual, intelektual, maupun profesional, pada dasarnya hakekat sebuah pendidkan adalah bagaimana memanusiakan manusia secara utuh. Dalam hal ini perlu ada kematangan, sehingga pendidikan menjadi sebuah proses pendewasaan diri seseorang dan masyarakat. Secara lebih khusus dijelaskan dalam Undang-undang sistem pendidikan Nasional nomor 20 tahun 2003, bahwa pendidikan adalah usaha sadar dan terencana untuk mewujudkan suasana belajar dan proses pembelajaran agar pesera didik secara aktif mengembangkan potensi dirinya untuk memiliki kekuatan spiritual keagamaan, pengendalian diri, kepribadian, kecerdasan, ahlak mulia, serta ketrampilan yang diperlukan dirinya, masyarakat, bangsa dan Negara.

Sejalan dengan tujuan pendidikan diatas maka sebuah lembaga pendidikan harus mampu mengerahkan semua daya dan berupaya untuk memenuhi dan mencapai tujuan pendidikan sesuai dengan tujuan pendidikan nasional tersebut. Sekolah sebagai salah satu lembaga pendidikan harus mampu mengerahkan segenap komponen yang ada didalamnya untuk berusaha memfasilitasi anak didik dalam rangka terselenggaranya proses pendidikan yang baik. Dalam meningkatkan 
pencapaian tujuan pendidikan perlu diperhatikan komponen-komponen yang mempengaruhi interaksi belajar mengajar. Komponen-komponen yang terlibat langsung yaitu bahan pelajaran, metode pengajaran, lingkungan belajar, guru dan siswa. Kelima komponen tersebut harus saling mendukung agar interaksi didalam proses belajar mengajar d apat berlangsung secara efektif dan efesien.

Bila salah satu diantara komponen tersebut terganggu maka hasil proses belajar akan tidak optimal. Meskipun kelima komponen tersebut tidak dapat dipisahkan dan saling mempengaruhi satu sama lain, namun sebenarnya siswa merupakan komponen utama, karena pada akhirnya pada diri siswa dapat diperoleh hasil dari hasil proses belajar mengajar langsung (Slameto, 2001 : 1). Untuk mengembangkan potensi anak didik secara optimal diperlukan metode yang sistimatis dan terarah. Kenyataan dilapangan pada lembaga-lembaga pendidikan formal khususnya metode pengelolaan pendidikan yang selama ini ditempuh termasuk aktualisasi kurikulum dalam pembelajaran, kurang memberikan kebebasan kepada peserta didik untuk mengembangkan berbagai kemampuan, kecerdasan (multy quation) seperti kecerdasan intelekual, emosional dan spriritual.

Dilain sisi secara khusus seorang guru harus mampu memfasilitasi anak didik agar terjadi kebebasan berfikir untuk mengembangkan kecerdasannya. Namun yang menjadi tantangan selama ini adalah ada tidaknya kompetensi seorang tenaga pendidik untuk mampu merencanakan pembelajaran seperti yang dimaksud diatas. Lebih lebih dalam pelajaran Ilmu Pengetahuan Sosial (IPS), terkesan sebagai pelajaran hafalan tidak menuntut kemampuan peserta didik untuk memecahkan suatu masalah.

Seorang guru IPS harus mampu mengkaji secara lebih mendalam kesulitan belajar siswa itu, sehingga secara profesional mampu mengatasi dan memecahkan kesulitan belajar yang dihadapi siswa, melalui rancangan dan penerapan berbagai metode atau model pendekatan pembelajaran yang memotivasi siswa untuk kreatif, inovatif dalam setiap proses pembelajaran yang menuntuk kemampuan peserta didik untuk memecahkan suatu masalah. Melalui metode pendekatan yang digunakan, seorang peserta didik mampu menguasai konsep atau teori, memahami permasalahan atau isu-isu dimasyarakat sesuai dengan konsep, mencari alternative untuk mengatasi masalah, dan selanjutnya merencanakan suatu tindakan untuk mengatasi dan mengantisipasi agar masalah yang dikaji tidak terulang kembali. 
Pemilihan metode, metode dan media pembelajaran itu harus bertumpu pada satu tujuan yang sama yaitu optimalisasi belajar dengan understanding dan bukan memorizing. Metode ini dapat membangkitkan minat, motivasi belajar siswa, sehingga akan nampak aktifitas belajarnya yang ditunjukkan dengan sikap belajar yang kreatif, menggairahkan, menakjubkan, menyenangkan, dalam suasana penuh kedamaian dan ketenangan, sehingga hasil belajar yang dicapai siswa maksimal.

\section{Definisi Operasional}

\section{Problem Based Introduction (PBI)}

Problem Based Introduction (PBI) adalah model pembelajaran berdasarkan permasalahan yang menitikberatkan pada aktivitas dan kreativitas siswa untuk mengembangkan kemampuan berfikir, pemecahan masalah, keterampilan intelektual yang sudah dimilikinya ketingkat yang lebih tinggi dalam memproses perolehan belajarnya (Wasis, dkk,2002; 24).

Model pengajaran ini sangat efektif untuk mengajarkan proses - proses berfikir tingkat tinggi, membantu siswa memproses informasi yang sudah dimilikinya dan membantu siswa membangun sendiri pengetahuan tentang dunia sosial dan fisik di sekitarnya.

Secara garis besar PBI terdiri dari menyajikan kepada siswa situasi masalah yang nyata dan bermakna yang dapat memberikan kemudahan kepada siswa untuk melakukan penyelidikan dan inguiri. Peranan guru dalam PBI adalah mengajukan masalah, mempasilitasi penyelidikan dan dialog siswa, serta mendukung belajar siswa. PBI diorganisasikan di sekitar kahidupan nyata yang menghindari jawaban sederhana dan mengundang berbagai pemecahan yang bersaing. Adapun ciri-ciri utama PBI meliputi (Wasis, dkk,2002;28):

1. Pengajuan pertanyaan atau masalah

Bukannya mengorganisasikan disekitar prinsip-prinsip atau keterampilan akademik tertentu, pembelajaran berdasarkan masalah mengorganisasikan pengajaran disekitar pertanyaan pertanyaan dan masalah yang dua-duanya secara sosial penting dan secara pribadi bermakna untuk sisw: 8 eka mengajukan situasi kehidupan nyata autentik, menghindari jawaban sederhana, dan memungkinam adanya berbagai macam solusi untuk situasi itu.

2. Berfokus pada keterkaitan antar disiplin 
Meskipun PBI mungkin berpusat pada mata pelajaran tertentu ( IPA, matematika,dan ilmu-ilmu sosial) masalah yang akan diselidiki telah dipilih benarbenar nyata agar dalam pemecahannya, siswa meninjau masalah itu dari banyak mata pelajaran.

3. Penyelidikan autentik

PBI mengharuskan siswa melakukan penyelidikan autentik untuk mencari penyelesaian nyata terhadap maslah nyata. Mereka harus menganalisis dan mendefinisikan masalah, mengembangkan hipotesis dan membuat ramalan, mengumpulkan dan menganalisis informasi, melakukan eksperimen, membuat inferensi, dan merumuskan kesimpulan.

4. Menghasilkan produk/karya dan memamerkannya

PBI menuntut siswa untuk menghasilkan produk tertentu dalam bentuk karya nyata dan peragaan yang menjelaskan atau mewakili bentuk penyelesaian masalah yang mereka temukan.

5. Kerja sama

PBI dicirikan oleh siswa yang bekerja sama satu sama yang lainnya, paling sering secara berpasangan atau dalam kelompok kecil. Bekerja sama memberikan motivasi untuk secara berkelanjutan terlibat dalam tugas kompleks dan memperbanyak peluang untuk berbagi inguiri, dialog dan untuk mengembangkan keterapilan sosial dan keterampilan berpikir.

Model PBI ini menekankan pada tiga prinsip penting yaitu :

1. Inquiri

Diawali dengan keinginan pengamatan dalam rangka untuk memamhami suatu konsep. Siklus yang terdiri dari kegiatan mengamati, bertanya, menganalisis, dan merumuskan teori, baik secara individu maupun bersama-sama dengan teman lainnya. Mengembangkan dan sekaligus mengggunakan keterampilan berpikir kritis.

1. Kontruktivis

Menurut teori kontrotivis, satu prinsip yang paling penting dalam psikologi pendidikan adalah guru tidak dapat hanya sekedar memberikan pengetahuan kepada siswa. Siswa harus membangun sendiri pengetahuan di dalam benaknya. Guru dapat memberikan kemudahan untuk proses ini, dengan memberikan kesempatan siswa untuk menemukan atau menerapkan ide-ide meraka sendiri, dan mengajar siswa 
menjadi sadar dan secara sadar menggunakan strategi mereka untuk belajar. Guru dapat memberi siswa anak tangga yang membawa siswa kepemahaman yang lebih tinggi, dengan catatan siswa sendiri yang harus memanjat tingkat tinggi

2. Berpikir tingkat tinggi

Siswa dilatih untuk menggunakan berpikir kritis dan kreatif dalam mengumpulkan data, memahami suatu isu, atau memecahkan masalah.

PBI biasanya terdiri dari lima tahap utama yang dimulai dengan guru memperkenalkan siswa dengan suatu situasi masalah dan diakhiri dengan penyajian dan analisis hasil kerja siswa. jika jangkauan masalahnya tidak terlalu kompleks, maka kelima tahapan tersebut mungkin dapat diselesaikan dalam waktu dua sampai tiga kali pertemuan. Namun untuk masalah-masalah yang kompleks mungkin akan membutuhkan setahun penuh untuk menyelesaikannya. Kelima tahapan tersebut disajikan pada table berikut :

Tingkah Laku Mengajar Model Problem Based Introduction

\begin{tabular}{|c|c|}
\hline Fase-fase & Tingkah laku guru \\
\hline Fase I & Guru menjelaskan tujuan pembelajaran, \\
\hline Orientasi siswa kepada masalah & $\begin{array}{l}\text { menjelaskan logistik yang dibutuhkan, } \\
\text { memotivasi siswa terlibat pada aktivitas }\end{array}$ \\
\hline Fase 2 & pemecahan masalah yang dipilih \\
\hline Mengorhanisasikan siswa untuk & Guru membantu siswa untuk mendefinisikan \\
\hline belajar & $\begin{array}{l}\text { dan mengorganisasikan tugas belajar yang } \\
\text { berhubungan dengan masalah tersebut. }\end{array}$ \\
\hline Fase 3 & Guru mendorong siswa untuk \\
\hline membimbing penyelidikan & mengumpulkan informasi yang sesuai, \\
\hline \multirow[t]{2}{*}{ individu maupun kelompok } & melaksanakan eksperimen untuk \\
\hline & $\begin{array}{l}\text { mendapatkan penjelasan dan pemecahan } \\
\text { masalah. }\end{array}$ \\
\hline Fase 4 & Guru membantu siswa dalam merencanakan \\
\hline Mengembangkan dan & dan menyiapkan karya yang sesuai seperti \\
\hline menyajikan hasil karya & laporan, video, dan model dan membantu \\
\hline & mereka untuk merbagi tugas dengan \\
\hline
\end{tabular}




\begin{tabular}{|l|l|}
\hline Fase 5 & temannya \\
Menganalisis dan mengevaluasi & Guru membanttu siswa untuk melakukan \\
proses pemecahan masalah & refleksi atau evaluasi terhadap penyelidikan \\
& $\begin{array}{l}\text { mereka dan proses-proses yang mereka } \\
\text { gunakan }\end{array}$ \\
\hline
\end{tabular}

PBI tidak dirancang untuk membantu guru memberikan informasi sebanyakbanyaknya kepada siswa. Melainkan dikembangkan untuk membantu siswa mengembangkan kemampuan berfikiir, pemecahan masalah, dan keterampilan intelektual serta menjadi pembelajaran yang otonom dan mandiri. Dengan bimbingan guru yang secara berulang-ulang mendorong dan mengarahkan mereka untuk menyelesaikan tugas-tugas itu secara mandiri.

Dengan menggunakan PBI, anak dapat dilatih untuk memecahkan masalah, melatih mengemukakan hipotesa, melatih merencanakan suatu eksperimen untuk menguji hipotesa itu, melatih untuk mengambil suatu kesimpulan dari sekumpulan data yang diperoleh anak-anak dari pelajaran itu, juga segi-segi lalinnya yang terdapat pada pelajaran sosial, sehingga PBI dapat merangsang anak untuk mencari jawaban, dan pada akhirnya aktivitas serta hasil belajar siswa dapat ditingkatkan.

\section{Hasil Belajar}

Menurut pengertian secara psikologis, belajar merupakan suatu proses perubahan yaitu perubahan tingkah laku sebagai hasil dari interaksi dengan lingkungannya dalam memenuhi kebutuhan hidupnya. Belajar juga dapat diartikan sebagai suatu proses usaha yang dilakukan seseorang untuk memperole suatu perubahan tingkah laku yang baru secara keseluruhan, sebagai hasil pengalamannya sendiri dalam interaksi dengan lingkungannya, (Slameto, 2001;2).

\section{Prestasi Belajar}

Untuk mendapatkan pengertian yang jelas tentang definisi hasil belajar, dibawah ini akan dikemukakan beberapa pendapat para ahli yang memberikan definisi tentang hasil belajar. Bahri (2002:24) menjelaskan bahwa hasil belajar adalah penilaian pendidikan tentang kemajuan siswa dalam segala hal yang dipelajari di sekolah yang menyangkut pengetahuan atau kecakapan, keterampilan yang dinyatakan sesudah proses penilaian dilakukan.Menurut Rusyan (2004:44) bahwa hasil belajar 
adalah hasil belajar seseorang yang sedikitnya menncakup tiga aspek, yaitu aspek kognitif, afektif, dan psikomotorik. Kemudian pendapat lain menjelaskan pula bahwa hasil belajar adalah :

Hasil belajar yang dicapai seseorang karena usahanya untuk memiliki sesuatu kecakapan, ilmu pengetahuann atau perubahan-perubahan yang dicapai seseorang dalam usahanya untuk memilki kecakapan maupun keterampilan tertentu. Perubahan-perubahan yang dicapai seseorang atau individu dalam proses belajar mengajar yang maliputi aspek pengetahuan, keterampilan, dan sikap (Poerwanto, 2009:12)

Dari beberapa pendapat diatas, dapat disimpulakan bahwa yang maksud dengan hasil belajar adalah hasil yang dicapai atau dimiliki oleh siswa setelah melalui proses belajar mengajar, hasil tersebut berupa perubahan-perubahan pada tiga ranah ranah kognitif, atau pengetahuan, ranah psikomotorik atau keterampilan, dan ranah afektif atau sikap. Seorang siswa yang telah melewati atau melalui proses belajar mengajar di sekolah dan tidak memiliki perubahan pada ketiga ranah tersebut, maka siswa tersebut tidak dinamakan berprestasi. Dengan demikian dapat diartikan secara mendalam bahwa hasil belajar sebagai hasil yang dicapai oleh siswa dalam sesuatu aktivitas pembelajaran di sekolah.

\section{Pengertian Hasil Belajar}

Pada prinsipnya, pengungkapan hasil belajar meliputi segenap ranah psikologi yang berubah seperti yang diungkapkan di atas, sebagai akibat pengalaman dan proses belajar. Namun demikian pengungkapan perubahan tingkah laku pada ketiga ranah itu, khususnya ranah afeksi siswa, sangat sulit dilakukan. Hal tersebut diakibatkan oleh perubahan yang terdapat pada ranah afeksi itu bersifat intangible (tak dapat diraba). Oleh karena itu, yang dapat dilakukan oleh seorang guru dalam penilaian ini adalah dengan hanya mengambil cuplikan perubahan tingkah laku yang dianggap penting dan diharapkan dapat mencerminkan perubahan - perubahan yang terjadi sebagai hasil belajar siswa

Kunci pokok untuk memperoleh ukuran dan data hasil belajar siswa adalah mengetahui garis-garis besar indikator atau petunjuk adanya prestasi tertentu yang di kaitkan dengan jenis prestasi yang hendak diungkapkan atau diukur (Muhibbin, 2005 ;150). 
Dalam menentukan batas minimum keberhasilan belajar siswa adalah berkaitan dengan upaya mengungkapkan hasil belajar. Jadi, tingkat hasil belajar dapat dilihat dari angka yang dicapai oleh siswa setelah mengikuti ujian semester yang diwujudkan dengan nilai rapor atau nilai laporan hasil belajar siswa, dengan ketentuan sebagai berikut :
a. angka $10=$ istimewa
b. angka $9=$ amat baik
c. angka $8=$ baik
d. angka $7=$ lebih dari cukup
e. angka $6=$ cukup
f. angka $5=$ tidak cukup
g. angka $4=$ kurang
h. angka $3=$ amat kurang
i. angka $2=$ buruk
j. angka $1=$ amat buruk

Dari ketentuan angka-angka tersebut diatas, maka jelaslah bahwa yang dikatagorikan siswa yang berhasil dalam belajar adalah siswa yang memiliki nilai mulai dari angka enam ( 6 ) : lebih dari cukup, tujuh ( 7 ) : baik, delapan ( 8 ) : amat baik, dan sembilan (9) : amat baik., seorang siswa yang memperoleh nilai 10 (sepuluh) merupakan siswa yang teristimewa di antara teman-temannya.

\section{Faktor -faktor Yang Mempengaruhi Prestasi Belajar Siswa}

Dalam proses belajar mengajar, terdapat beberapa faktor yang saling mempengaruhi. Secara umum factor yang mempengaruhi prestasi belajar adalah factor intern dan ekstern (Slameto,2001:54). Prestasi belajar merupakan hasil dari interaksi dari komponen-komponen yang berasal dari luar siswa ( ekstern) dan dari dalam siswa (intern ), namun peneliti akan lebih terfokus pada metode mengajar.

a. Faktor intern

Faktor intern yaitu faktor yang ada dalam diri individu yang sedang belajar. Faktor ini dapat dibagi menjadi 2 ( dua ) yaitu jasmaniah dan rohaniah.

Faktor Jasmaniah ( Psikologis )

Faktor jasmaniah ini dapat dibagi ke dalam beberapa indicator, yaitu "factor kesehatan d an ccat tubuh". Kesehatan berarti keadaan baik segenap badan ser dari 
penyakit. ta bagian - bagiannya atau bebas dari penyakit. Kesehatan adalah keadaan atau hal sehat. Kesehatan seseorang berpengaruh terhadap belajarnya. Proses belajar seseorang akan terganggu jika kesehatannya terganggu, selain itu juga, ia akan cepat mengalami kelelahan, kurang bersemangat, mudah pusing, mengantuk jika badan lemah atau ada gangguan-gangguan dan kelainan fungsi alat indra serta tubuh.

Pendapat ini menjelaskan bahwa “jasmani yang kkurang sehat dapat mempengaruhi semangat dan intensitas dalam mengikuti pelajaran, apalagi jika kepala pusing misalnya sangat besar pengaruhnya terhadap prestasi belajar siswa" (Muhibbin, 2005:132).

Faktor Rohaniah (psikologis)

Banyak faktor psikologis yang dapat mempengaruhi prestasi belajar siswa. Namun diantara faktor - faktor rohaniah yang dipandang esensial itu adalah "intelegensi, perhatian, bakat, minat, motivasi, kematangan, dan kesiapan." (Selameto,2001:55). Faktor rohaniah ini merupakan yang menentukan keberhasilan belajar atau prestasi siswa dalam belajar. Bagaimanapun siapnya faktor lain tanpa didukung oleh faktor rohaniah ini.

\section{Karakteristik Mata Pelajaran Ilmu Pengetahuan Sosial untuk Sekolah Dasar (SD)/Madrasah Ibtidaiyah (MI)}

Ilmu Pengetahuan Sosial (IPS) merupakan salah satu mata pelajaran yang diberikan mulai dari SD/MI/SDLB sampai SMP/MTs/SMPLB. IPS mengkaji seperangkat peristiwa, fakta, konsep, dan generalisasi yang berkaitan dengan isu sosial. Pada jenjang SD/MI mata pelajaran IPS memuat materi Geografi, Sejarah, Sosiologi, dan Ekonomi. Melalui mata pelajaran IPS, peserta didik diarahkan untuk dapat menjadi warga negara Indonesia yang demokratis, dan bertanggung jawab, serta warga dunia yang cinta damai. Di masa yang akan datang peserta didik akan menghadapi tantangan berat karena kehidupan masyarakat global selalu mengalami perubahan setiap saat.

Oleh karena itu mata pelajaran IPS dirancang untuk mengembangkan pengetahuan, pemahaman, dan kemampuan analisis terhadap kondisi sosial masyarakat dalam memasuki kehidupan bermasyarakat yang dinamis. Mata pelajaran IPS disusun secara sistematis, komprehensif, dan terpadu dalam proses pembelajaran menuju kedewasaan dan keberhasilan dalam kehidupan di masyarakat. Dengan 
pendekatan tersebut diharapkan peserta didik akan memperoleh pemahaman yang lebih luas dan mendalam pada bidang ilmu yang berkaitan.

Mata pelajaran IPS bertujuan agar peserta didik memiliki kemampuan sebagai berikut.

1. Mengenal konsep-konsep yang berkaitan dengan kehidupan masyarakat dan lingkungannya

2. Memiliki kemampuan dasar untuk berpikir logis dan kritis, rasa ingin tahu, inkuiri, memecahkan masalah, dan keterampilan dalam kehidupan sosial

3. Memiliki komitmen dan kesadaran terhadap nilai-nilai sosial dan kemanusiaan

4. Memiliki kemampuan berkomunikasi, bekerjasama dan berkompetisi dalam masyarakat yang majemuk, di tingkat lokal, nasional, dan global. Ruang lingkup mata pelajaran IPS meliputi aspek-aspek sebagai berikut.

1. Manusia, Tempat, dan Lingkungan

2. Waktu, Keberlanjutan, dan Perubahan

3. Sistem Sosial dan Budaya

4. Perilaku Ekonomi dan Kesejahteraan.

\section{Metodologi Penelitian}

Penelitian Tindakan Kelas ini berlangsung dalam beberapa tahapan. Tahapan-tahapan itu meliputi ; tahap refleksi awal, tahap perencanaan, tahap tindakan/observasi, dan tahap refleksi. Tahapan-tahapan itu dapat di gambarkan dalam skema dibawh ini:

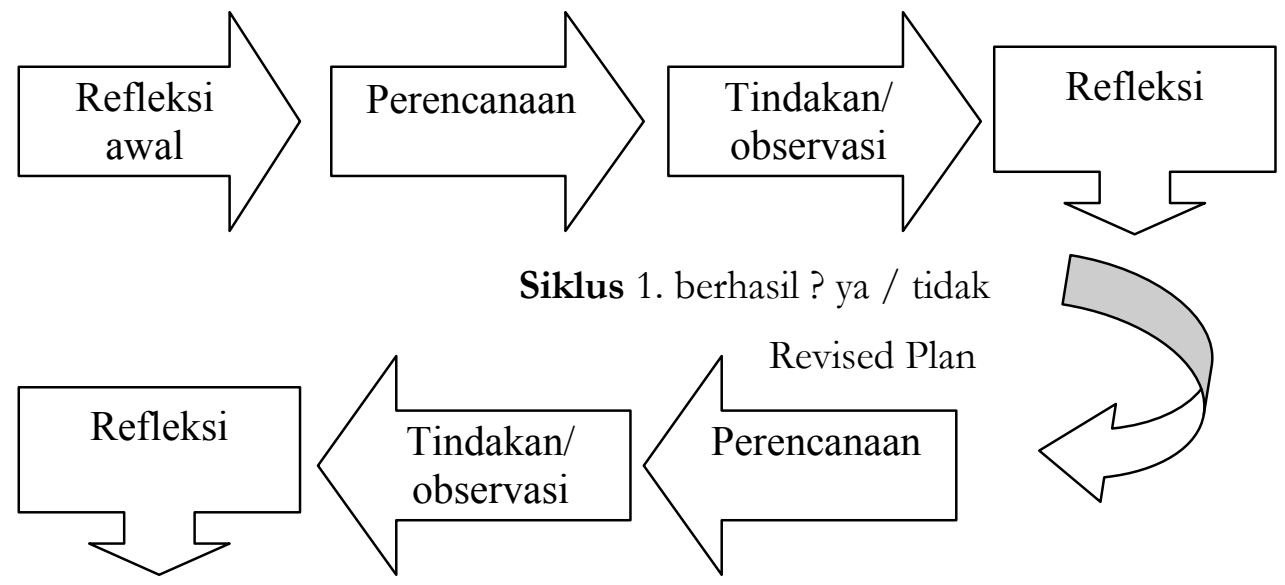

Siklus 2. berhasil ? ya / tidak

(Riyanto, 2001:58) 


\section{Tahap Perencanaan}

Dalam tahap perencanaan dilakukan kegiatan-kegaiatan sebagai berikut :

a. Membuat post test dan free test

b. menetapkan alokasi waktu

c. menyiapkan Rencana Pelaksanaan Pengajaran (RPP) dan LKS yang mengacu pada Kurikulum Satuan Tingkat Pendidikan ( KTSP) 2006

d. menyiapkan instrument penelitian : 1). Tes hasil belajar

\section{Tahap Pelaksanaan Tindakan}

Adapun tahapan kegiatan pembelajaran yang dilaksanakan :

a. Memberikan pertanyaan pada siswa untuk mengajukan masalah

b. Melaksanakan pembelajaran dengan menggunakan Rencana Persiapan Pembelajaran model Problem Based Introduction (PBI)

c. Melaksanakan observasi selama kegiatan belajar mengajar

\section{Tahap Observasi}

Kegiatan yang dilakukan dalam tahap ini adalah :

a. melaksanankan tes akhir

b. memberikan tugas kelompok

c. menganalisis tes akhir dan angket

d. menganalisis hasil observasi

\section{Tahap Refleksi}

Refleksi dilakukan berdasarkan hasil observasi terhadap prilaku siswa. Adanya kekurangan-kekurangan atau hambatan-hambatan selama mengikuti proses pembelajaran, selanjutnya dilakukan lengkah-langkah perbaikkan untuk pelaksanaan proses pembelajaran pada pertemuan berikutnya.

\section{Data Hasil Penelitian}

Pada bagaian ini dikemukakan tentang hasil yang dicapai dalam proses penelitian. Secara berurutan akan dibahas mengenai (1) Deskripsi data, (2) pelaksanaan siklus penelitian

Table 4.1. Data Hasil Belajar siswa Kelas V Mata Pelajaran IPS

\begin{tabular}{|c|c|c|}
\hline No & Nama & Nilai \\
\hline
\end{tabular}




\begin{tabular}{|c|c|c|c|c|c|}
\hline & & Awal & Siklus I & Siklus II & Siklus III \\
\hline 1 & Agus Sapriadi & 4 & 6,5 & 8 & 8 \\
\hline 2 & Ahmad wildan & 6,5 & 7 & 9 & 9 \\
\hline 3 & Alpian Katriadi & 5 & 6,5 & 8,5 & 8,5 \\
\hline 4 & Apriana & 4 & 6 & 6 & 6 \\
\hline 5 & Candra Saputra & 5 & 6 & 6 & 6,5 \\
\hline 6 & Eka Rizqia Febriani & 3 & 6,5 & 8,5 & 8,5 \\
\hline 7 & Rianto & 4 & 6,5 & 6,5 & 7,5 \\
\hline 8 & Eni Yuliani & 4 & 5 & 7 & 7 \\
\hline 9 & Hilma Sucita & 6,5 & 7 & 9 & 9 \\
\hline 10 & Herni Juliana & 4 & 5 & 8,5 & 8,5 \\
\hline 11 & Hamdi Ahmad Basir & 4 & 6 & 8 & 8 \\
\hline 12 & Lisa Suryani & 6,5 & 7 & 8,5 & 8,5 \\
\hline 13 & Muliani & 4 & 6,5 & 7,5 & 7,5 \\
\hline 14 & M. Nurul Watoni & 6,5 & 7 & 8 & 8 \\
\hline 15 & M. Azhari & 4 & 6 & 9 & 9 \\
\hline 16 & Nur aini & 4 & 5 & 8,5 & 8,5 \\
\hline 17 & Nurul Wahidah & 3 & 4,5 & 6 & 7 \\
\hline 18 & Nurul Aini & 3 & 7,5 & 7 & 9 \\
\hline 19 & Riska Ida Apriani & 3 & 6 & 6 & 6 \\
\hline 20 & Rukaiyah & 44 & 6,5 & 8 & 8 \\
\hline 21 & Susanti Sulastri & & 7 & 8,5 & 8,5 \\
\hline 22 & Takwil & 3 & 5 & 7 & 7 \\
\hline 23 & Yogi Suciawan & 3 & 5,5 & 7 & 7 \\
\hline 24 & Zulkarnain & 4 & 5 & 6 & 6 \\
\hline \multicolumn{2}{|c|}{ Jumlah Nilai } & 104,5 & 150,5 & 182,2 & 186,5 \\
\hline \multicolumn{2}{|c|}{ Nilai Rata - rata } & 4,35 & 6,2 & 7,5 & 7,77 \\
\hline \multicolumn{2}{|c|}{ Ketuntasan } & & $25 \%$ & $75 \%$ & $83.33 \%$ \\
\hline
\end{tabular}


Refleksi

Mencermati hasil observasi aktivitas guru dalam pelaksanaan tindakan siklus 1, maka hal yang harus diperhatikan pada siklus 2, dan 3 adalah :

1. Menjelaskan tujuan pembelajaran, menjelaskan logistik yang dibutuhkan, memotivasi siswa terlibat pada aktivitas pemecahan masalah yang dipilih

2. Memberikan informasi yang sesuai, melaksanakan eksperimen untuk mendapatkan penjelasan dan pemecahan masalah.

3. Merencanakan dan menyiapkan karya yang sesuai seperti laporan, video, dan model dan membantu mereka untuk membagi tugas dengan temannya

4. Membantu siswa untuk melakukan refleksi atau evaluasi terhadap penyelidikan mereka dan proses-proses yang mereka gunakan.

\section{Refleksi}

Mencermati hasil observasi aktivitas siswa dalam pelaksanaan tindakan siklus 1 , maka hal yang harus diperhatikan pada siklus 2, dan 3 adalah :

1. Mendefinisikan dan mengorganisasikan tugas belajar yang berhubungan dengan masalah yang dihadapi.

2. Mengumpulkan informasi yang sesuai, melaksanakan eksperimen untuk mendapatkan penjelasan dan pemecahan masalah.

3. Merencanakan dan menyiapkan karya yang sesuai seperti laporan, video, dan model dan membantu mereka untuk membagi tugas dengan temannya

4. Melakukan refleksi atau evaluasi terhadap penyelidikan mereka dan proses-proses yang mereka gunakan

\section{B. Analisis Data}

1. Peningkatan Hasil Belajar

Setelah pembelajaran siklus I

$=\mathrm{R}$ siklus $1-\mathrm{R}$ tes awal

$=6,2-4,35$

$=1,85$

Persentasenya $=\frac{1,85}{4,35} \times 100 \%$

$$
=42,52 \%
$$


Setelah pembelajaran siklus 2

$=\mathrm{R}$ siklus $2-\mathrm{R}$ siklus 1

$=7,5-6,2$

$=1,3$

$\begin{aligned} \text { Persentasenya } & =\frac{1,3}{6,2} \times 100 \% \\ & =20,96 \%\end{aligned}$

Setelah pembelajaran siklus 3

$=\mathrm{R}$ siklus $3-\mathrm{R}$ siklus 2

$=7,77-7,5$

$=0,27$

Persentasenya $=\frac{0,27}{7,5} \times 100 \%$

$$
=3,6 \%
$$

Total Peningkatan Hasil Belajar Siswa

$$
\begin{aligned}
& =42,52 \%+20,96 \%+3,6 \% \\
& =67,08 \%
\end{aligned}
$$

2. Peningkatan Aktivitas Guru

$$
\begin{aligned}
& =\text { Skor siklus } 2-\text { skor siklus } 1 \\
& =25-22 \\
& =3
\end{aligned}
$$

Persentase keterlaksanaan program dalam RPP

$$
\begin{aligned}
& =\frac{3}{22} \times 100 \% \\
& =13,63 \%
\end{aligned}
$$

3. peningkatan Aktivitas Siswa

$$
\begin{aligned}
& =\text { Skor siklus } 2-\text { skor siklus } 1 \\
& =25-21 \\
& =4 \\
& \text { Persentase }=\frac{4}{21} \times 100 \% \\
& =19,04 \%
\end{aligned}
$$




\section{Catatan Akhir}

Berdasarkan data yang diperoleh dan setelah dianalisis maka dapat disimpulkan bahawa :

1. Penerapan Model Problem Based Introduction dapat meningkatkan hasil belajar dan aktivitas belajar IPS Kompetensi Mengenal Jenis-jenis Usaha dan Kegiatan Ekonomi di Indonesia pada siswa kelas V di MI NW Peseng

2. Prestasi belajar IPS Ekonomi dapat ditingkatkan dengan menggunakan Model Problem Based Introduction terhadap prestasi belajar IPS kompetensi Mengenal Jenis-jenis Usaha dan Kegiatan Ekonomi di Indonesia pada siswa kelas Vdi MI NW Peseng

3. Ada pengaruh antara Model Problem Based Introduction terhadap prestasi belajar IPS kompetensi Mengenal Jenis-jenis Usaha dan Kegiatan Ekonomi di Indonesia pada siswa kelas Vdi MI NW Peseng

Hal diatas ditunjukkan dengan :
a. Peningkatan Hasil Belajar
$=67.08 \%$
b. Peningkatan aktivitas Siswa
$=19,04 \%$
c. Peningkatan kinerja Guru
$=13,63 \%$

\section{Daftar Rujukan}

Akib, Zaenal, 2002. Profesionalisme Guru dalam Pembelajaran. Surabaya

Arikunto, Suharsimi, 2001, Dasar Dasar Evaluasi Pendidikan. Bina Aksara Bandung.

Arikunto, Suharsimi,2008, Prosudur Penelitian (Suatu Pendekatan Praktik), Rineka Cipta, Jakarta.

Departemen Pendidikan dan Kebudayaan, 1995. Petunjuk Teknis Penilaian. Jakarta

Djamarah, Bahri S., 2000, Psikologi Belajar, Rineka Cipta, Jakarta.

Hamalik Oemar, 2003, Proses Belajar Mengajar, Jakarta, PT Bumi Aksara.

Riduwan, 2004, Belajar Mudah Penelitian, Bandung: Alfabeta

Riyanto Yatim, 2001. Metodologi Penelitian Pendidikan. Surabaya

Satmoko, Retno S. 1993. Pengantar Pendidikan Jilid I. Jakarta; Direktorat Jendral Kelembagaan Agama Islam.

Slameto,2001. Evaluasi Pendidikan. Bandung

Slameto, 2003, Belajar dan Faktor-faktor yang Mempengarubinya, Rineka Cipta, Jakarta. 
Wasis dkk, 2002. Beberapa Model Pengajaran dan strategi Belajar Dalam Pembelajaran IPA. Direktorat Pendidikan Dasar dan Menengah. Jakarta

Wasis, dkk, 2002. Beberapa Teori yang Melandasi Pengembangan Model-model Pengajaran. Direktorat Pendidikan Dasar dan Menengah. Jakarta. 